\title{
EXTREME Cold Discomfort in EXTREME Hot Climates, A STUDY OF BUILDING OVERCOOLING IN OFFICE BUILDINGS IN QATAR
}

\author{
Abdulla Alnuaimi* and Sukumar Natarajan* \\ Department Architecture and Civil Engineering, University of Bath, Bath, United Kingdom
}

\begin{abstract}
Indoor cold discomfort in Qatar due to "building overcooling" is increasing, as air-conditioning prevails, and global temperatures rise. Overcooling is not dependent only on the inappropriate design of cooling systems, but on "international" thermal comfort standards that are not customized for warm climates. International standards are unintentionally biased towards cooler climates and cultures, the application of which in warm climates result in colder indoor temperatures observed by building occupants and increased cooling energy demand. Overcooling is an over-expenditure of energy, resulting in uncomfortably cold indoor thermal conditions, and unnecessary carbon emissions. In this study, the analysis of field data from 6 office buildings in Doha in a range of indoor thermal conditions and investigation of overcooling on occupant comfort and building performance is conducted. The analysis uncovers over $35 \%$ of occupants state being uncomfortably cold and a consensus across the surveys highlight comfortable temperatures higher by $2^{\circ} \mathrm{C}$ from current setpoint temperatures. Greater occupant comfort and energy efficiency are found by increasing the indoor temperature setpoints investigated through thermal comfort analysis and energy simulation models. Around $50 \%$ decrease in occupant discomfort and a 15\% decrease in cooling energy demand is found. Such an adjustment in Qatar would improve occupant comfort levels and reduce cooling energy demand throughout the existing office building stock.
\end{abstract}

Keywords: Building Energy; Extreme Climates; Overcooling; Thermal Comfort.

$$
\text { البرد شديد الازعاج في المناخات شديدة الحرارة: دراسة عن التبريد المفرط في المباني المكتبية في قطر }
$$

الملخص: في قطر يزداد الانز عاج من البرد في المباني الناتج عن التبريد المفرط بسبب الاستخدام المتنامي لأنظمة التكييف،

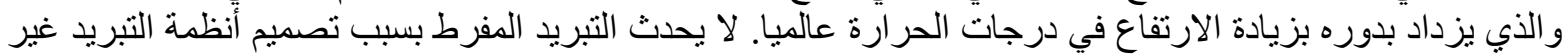

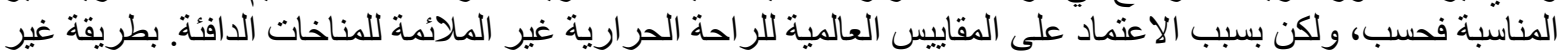

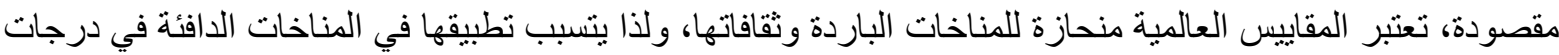

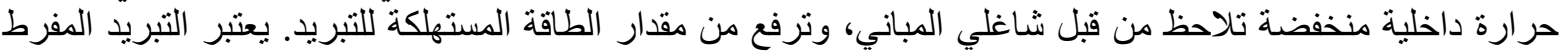

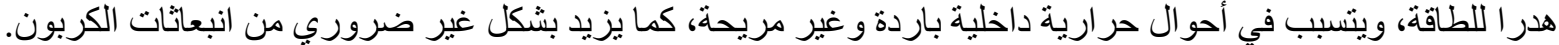

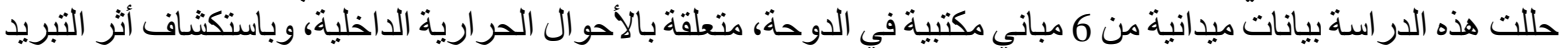

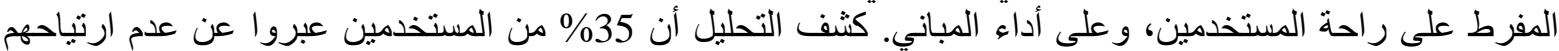

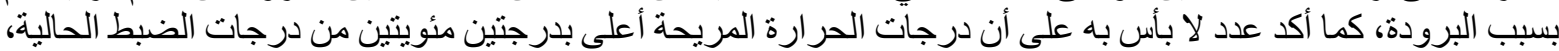

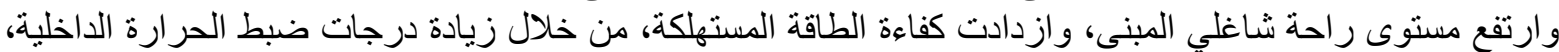

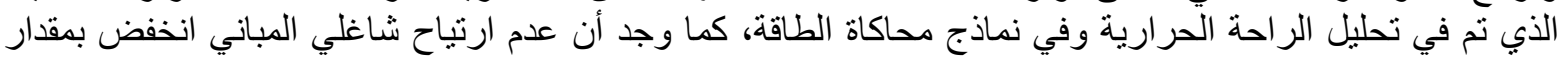

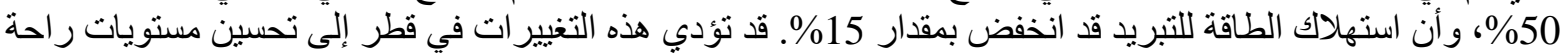
شاغلي المباني، وتقليل الطاقة المستهلكة للتبريد في المباني المكتبية القائمة في قطر . 


\section{INTRODUCTION}

Globally, most of the human population resides in the built environment which is constantly growing at the highest rate ever seen in human history. Nearly $40 \%$ of the total energy produced, which is generated primarily from non-renewable energy sources, is consumed by the built environment (EIA, 2019). This built environment energy consumption is estimated to cause about a third of global carbon emissions (Stocker et al., 2013; IEA, 2018). In warm climates such as Qatar, space cooling for buildings as an end-use is the largest energy consumer, on average $40 \%$ of the building energy consumption is used for space cooling, (IEA, 2018). Building space cooling globally is a substantial energy use sector that accounts for $16 \%$ of total energy use in buildings and is expected to triple by the year 2050 (IEA, 2018).

However, anecdotal evidence suggests that overcooling in warm climates such as Qatar is occurring and is a likely cause of energy waste. Building overcooling is additionally linked to overall occupant discomfort causing negative health impacts and lower productivity (Chen and Chang, 2012; Brager and Arens, 2015). As demand for building cooling is expected to increase, likewise the occurrence of overcooling in warm climate built environments will persist. Understanding the thermal environments and the approach to thermal comfort in Qatari buildings would uncover, building overcooling, its impacts, and possible solutions.

\subsection{Qatar Thermal Comfort}

Qatar's climate is classified as a hot desert climate (Bwh) according to Köppen and Geiger (Köppen, 1918). As the country experiences a hot climate with an annual temperature average of $27.5^{\circ} \mathrm{C}$, maintaining thermal comfort in the Qatari built environment necessitates active cooling means. Over $55 \%$ of the total energy production in Qatar is consumed by (Ayoub et al., 2014). Roughly 60\% of the energy consumed in buildings in Qatar is a result of heating, ventilation, and air-conditioning (HVAC) systems (Ayoub et al., 2014). As Qatar does not have a specific local thermal comfort standard, international standards are the country's default guidelines for indoor thermal comfort. Qatar's leading green building rating system the Global Sustainability Assessment System (GSAS) (GORD, 2019) specifically relies on the American Society of Heating Refrigeration and Air Conditioning Engineers (ASHRAE) Standard 55 (ASHRAE, 2010) and the combined Predicted Mean Vote (Fanger, 1970) as the mean for evaluating thermal comfort in Qatar. Evermore, the international community is developing greater awareness that a universal interpretation of thermal comfort standards leads to applications in extreme climates that result in occupant discomfort and unnecessary expenditure of energy.

The development of several international standards such as the ISO (International Organization for
Standardization) 7730 (ISO, 2005), the ASHRAE Standard 55 (ASHRAE, 2010), and the EN (European Standard) 16798-1:2019 (EN, 2019) have been initially focused in the cooler regions of North America and Europe. Therefore, the associated metrics within these standards for establishing thermal comfort come into question, as they have been developed through data from occupants of these regions (Fanger, 1970; Toftum and Fanger, 2002). The PMV has been questioned by researchers for its applicability in extreme climates as the deviation between the actual sensation vote averages and the PMV have been frequently observed in field studies (De Dear and Brager, 1998; Humphreys and Nicol, 2002; Indraganti and Boussaa, 2017).

In thermal comfort research conducted in Qatar across 5 private buildings and 4 public buildings, the use of the PMV to assess actual occupant comfort has been found to overestimate the occupant's response (Indraganti and Boussaa, 2017). The PMV was found to assume a warmer sensation than what is recorded by the occupant provided TSV across all buildings (Indraganti and Boussaa, 2017). In addition, within the same study in Qatar, the comfort temperature evaluated across the entire study was $24.1^{\circ} \mathrm{C}$ which is warmer than suggested setpoint temperatures by GSAS (GORD, 2019) guidelines (Indraganti and Boussaa, 2017). It is apparent that by using such standards, an overcooled building occupant population is observed. By understanding the thermal comfort behaviours of the local building occupants in Qatar, the extent of building overcooling in this climate can be determined.

\subsection{Building Overcooling}

Overcooling is a phrase used to represent the phenomenon of excessive cooling within the built environment that is caused by the purposeful expenditure of energy, which results in occupant cold discomfort. Overcooling has become a common occurrence in buildings across warm climates such as Qatar (Cena and De Dear, 2001; Mendell and Mirer, 2009; Yang, Wong and Zhou, 2014; Zhou et al., 2016; Paliaga et al., 2019). In the media, overcooling is discussed with anecdotal accounts in the built environment in places such as offices and shopping complexes (Murphy, 2015; Williams, 2016; Green, 2019). Overcooling is discussed in terms such as a "summer freeze" and "freezing" which highlight the shared feeling of being "too cold" indoors, while outdoors is much warmer (Murphy, 2015; Williams, 2016; Green, 2019). Overcooling is not only associated with an increase in occupant discomfort but likewise, the unnecessary consumption of resources.

As building cooling is a significant energy end-use in Qatar, any overcooling in buildings directly results in wasteful energy use and unnecessary carbon emissions. Researchers in the US have estimated that in 2012 overcooling had an energy impact of 103,929 GWh, an environmental impact of over 50,000 kt CO2 emissions, and roughly 10 billion USD (Derrible and Reeder, 2015; Aghniaey and Lawrence, 2018). 
To assess overcooling in buildings, thermal comfort principles in the literature provide several metrics for evaluating building occupants' discomfort. Subjective metrics like the thermal sensation vote (TSV), thermal preference vote (TPV), thermal acceptance vote (TAV), and thermal comfort vote (TCV), are used to directly assess building occupants' comfort. The TSV and TPV are metrics that indicate the occupant's perception of the thermal environment based upon direct feedback on a thermal scale ranging from "cold" to "hot" votes. The TAV and TCV indicate the occupant's acceptance or comfort level of space, based upon occupant feedback on an acceptance/satisfaction scale. Likewise, to assess discomfort, temperature metrics define discomfort in relation to predetermined temperature-based criteria based upon idealistic temperature conditions (Huh and Brandemuehl, 2008; May-Ostendorp et al., 2011; Hu and Karava, 2014; Pisello and Cotana, 2014; Kaam et al., 2017; Wang et al., 2017). Temperature setpoints and ranges can be used which include seasonal air temperatures ranges and humidity alongside external air temperatures to indicate discomfort (Auliciems and De Dear, 1986; ISO, 2005; CEN, 2007; Mendell and Mirer, 2009; ASHRAE, 2010; Fang, Winkler and Christensen, 2011; Bennett et al., 2012; Shi et al., 2015; CIBSE, 2015; Abou-Ziyan, Alajmi and Ghoneim, 2016; Landsman, Brager and Doctor-Pingel, 2018; Estrella Guillén, Samuelson and Cedeño Laurent, 2019). Further to assess discomfort, model metrics such as the Predicted Mean Vote (PMV) can be used. In the case of the PMV, overcooling is described as a PMV below -0.5 since the PMV model usually defines thermally comfortable votes to occur between -0.5 to +0.5 for most building types such as offices (Fanger, 1970; Palme et al., 2007; Samiuddin and Budaiwi, 2018).

Establishing the extent of overcooling in buildings in warm climates has been conducted using subjective thermal comfort metrics (Alnuaimi and Natarajan, 2020). Combining the TSV and TPV has found building occupants in warm climates in the global south are on average 16\% overcooled (Alnuaimi and Natarajan, 2020). In addition, the widespread adoption of international standards in warm regions such as the Middle East and North Africa has been found to be a direct source of occupants overcooling determined through occupant responses (Elnaklah et al., 2021). As building overcooling is unwanted based upon building occupants' feedback. Assessing the extend of this overcooling is established through the occupants' responses. Further, the evaluation of overcooling in Qatar offices is considered alongside the associated energy consumption.

\section{METHODOLOGY}

Establishing the effect of overcooling on cooling energy demand in typical office buildings in Qatar involves (i) an estimation of the extent of cold discomfort, in Qatar through occupant responses in surveyed buildings, (ii) evaluating a comfort temperature setpoint, which would eliminate the cold discomfort and not result in hot discomfort, and (iii) evaluating the reduction in cooling energy demand possible through the comfort temperature in contrast to the observed temperature.

\subsection{Data Collection}

The field data were collected during the summer of 2019, starting in May and ending in August, with a total of 6 visits to 4 private and 2 public office buildings in Qatar. Buildings with medium to large office working conditions were selected as they represent the typical office conditions in Qatar. The summer season was targeted for the data collection as the summer period within warmer climates heavily rely on active cooling systems to offset the heat. An anonymous questionnaire incorporating standardized thermal comfort questions found in ISO 7730 was utilized for the data collection. Consent, as well as an explanation for the data collection, was given from all building occupants participating in the data collection. The questionnaires were produced in both English and Arabic format. The questionnaires were deployed to collect qualitative metrics such as the TSV and the TPV directly from the building occupants on a continuous seven-point thermal scale. The questionnaires were distributed to building occupants that have been in a prolonged seated position to ensure a stable metabolic level corresponding to seating.

The environmental parameters in the field data collection were measured using calibrated thermal environment measurement sensors that conform to ISO 7730. The air temperature $\left(\mathrm{T}_{\mathrm{a}}\right)$, mean radiant temperature $\left(\mathrm{T}_{\mathrm{mrt}}\right)$, relative humidity $(\mathrm{RH})$, and air velocity $\left(A_{v}\right)$ were taken as spot readings at the desk of each building occupants' workplace, which was conducted for every building occupant in the study (Figure 1).

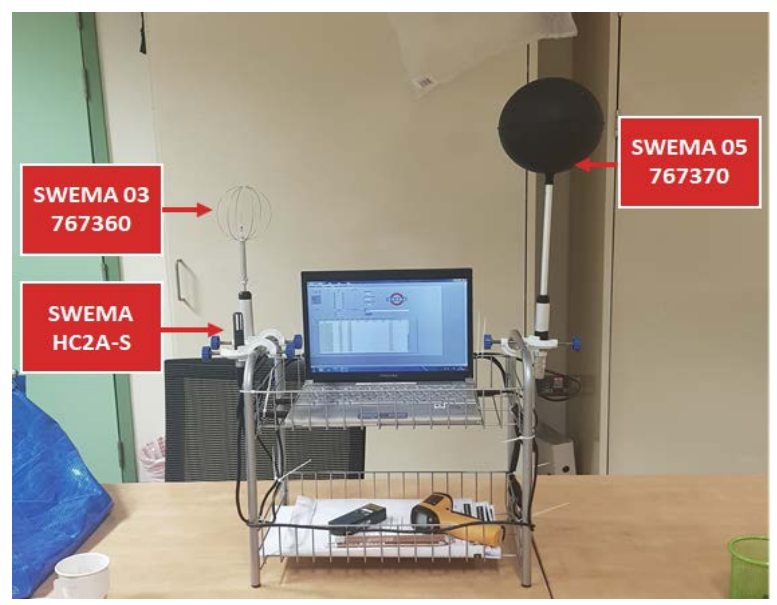

Figure 1. Thermal comfort measurement instruments attached to data logging software during the collection of data for the environmental parameters. 
Air temperature and relative humidity were measured using the Swema HC2A-S air humidity probe, mean radiant temperature was measured using the Swema 05767370 globe temperature sensor, and air velocity was measured using the Swema 03767360 anemometer which is summarised in Table 1 . The clothing insulations values were established by the ASHRAE index for non-western clothing ensembles (Havenith et al., 2015) which was available for the occupants to select the clothing combination that best represented what they were wearing during their survey participation. The metabolic rate of work was uniformly applied as that for seating as surveying of the occupants was focused on office working occupants that have been seated for twenty minutes or more. The environmental parameters, the clothing insulation value (CLO), and the metabolic rate of work (MET) were assessed to illustrate each building's general thermal condition. The parameters were summarized for each building to represent the maximum, mean, standard deviation, and minimum value for each collected parameter recorded during the time of the study.

Further questions within the survey that ask whether the occupants are "thermally comfortable" and if they feel "too cold" under the current indoor thermal conditions were deployed in the survey. Both these questions are plotted for each binned indoor temperature to examine the voting pattern on comfort and feeling too cold in the surveyed office buildings in Qatar.

\subsection{Data Analysis}

Analysis of the collected data from the surveyed buildings attempts to demonstrate the extent of discomfort and what constitutes comfort based upon direct occupant responses. The occupant responses are analysed in a spectrum of indoor temperature conditions collected from the survey building within this study.

Table 1. Summary of Sensors’' Specifications.

\begin{tabular}{|c|c|c|c|}
\hline Instrument & $\begin{array}{c}\text { Paramete } \\
r\end{array}$ & Range & Accuracy \\
\hline \multirow{2}{*}{$\begin{array}{l}\text { SWEMA } \\
\text { HC2A-S Air } \\
\text { Humidity } \\
\text { Probe }\end{array}$} & $\mathrm{T}_{\mathrm{a}}$ & $\begin{array}{c}-50 \text { to } \\
+100^{\circ} \mathrm{C} \\
\end{array}$ & $\begin{array}{c} \pm 0.1^{\circ} \mathrm{C} \text { at } 10- \\
30^{\circ} \mathrm{C}\end{array}$ \\
\hline & RH & $\begin{array}{c}0 \text { to } \\
100 \% \\
\mathrm{RH} \\
\end{array}$ & $\begin{array}{c} \pm 0.8 \% \mathrm{RH} \text { at } \\
10-30^{\circ} \mathrm{C}\end{array}$ \\
\hline $\begin{array}{l}\text { SWEMA } 05 \\
767370 \\
\text { Globe } \\
\text { Temperature } \\
\text { Sensor }\end{array}$ & $\mathrm{T}_{\mathrm{r}}$ & $\begin{array}{l}0 \text { to }+50 \\
{ }^{\circ} \mathrm{C}\end{array}$ & $\begin{array}{c} \pm 0.1^{\circ} \mathrm{C} \text { at } 0- \\
50^{\circ} \mathrm{C}\end{array}$ \\
\hline $\begin{array}{l}\text { SWEMA } 03 \\
767360 \\
\text { Anemometer }\end{array}$ & $A_{v}$ & $\begin{array}{l}0.05- \\
3.00 \\
\mathrm{~m} / \mathrm{s} \text { at } \\
15 \text { to } \\
30^{\circ} \mathrm{C}\end{array}$ & $\begin{array}{c} \pm 0.04 \mathrm{~m} / \mathrm{s} \text { at } \\
0.05 \text { to } 1.00 \\
\mathrm{~m} / \mathrm{s} \\
\pm 4 \% \text { read value } \\
\text { at } 1.00 \text { to } 3.00 \\
\mathrm{~m} / \mathrm{s} \\
\text { at } 15 \text { to } 30^{\circ} \mathrm{C}\end{array}$ \\
\hline
\end{tabular}

Initially, the individual values for TSV and TPV collected from each building occupant are accumulated, and average values are evaluated for both TSV and TPV for each surveyed building. In addition, the PMV and PPD for each individual building occupant are calculated and average values are evaluated for each surveyed building.

The calculated average for the TSV, TPV, PMV, and PPD are summarised and serve to contrast observed occupant thermal responses to that of international standard models deployed within Qatar for each surveyed building. The TSV and the TPV are classified to correspond to a certain thermal classification depending on the location of the vote on the seven-point scale which is as either a cold discomfort $[-3,-1)$, neutral comfort $[-1,+1]$, or hot discomfort $(+1,+3]$ classification. The hot discomfort percentage (HD) is evaluated by accounting for all the hot discomfort classified votes from the TSV and TPV against the total votes within that building or temperature range. Likewise, by accounting for all the cold discomfort classified votes in the TSV and TPV the cold discomfort percentage (CD) is evaluated.

The hot and cold discomfort percentages are calculated for the entire study binned by $1^{\circ} \mathrm{C}$ indoor operative temperature extracted from the combination of the TSV and TPV. Evaluating the HD and CD within a spectrum of indoor operative temperatures represents the occupant's attitude towards hot and cold discomfort within various temperatures. Hotter temperatures are expected to illustrate higher HD values and colder temperatures with higher $\mathrm{CD}$ values which would confirm the effectiveness of HD and CD in evaluating discomfort. In addition, the HD and CD are calculated for each building in the study to illustrate occupants' attitudes towards hot and cold discomfort within each surveyed building. Further, a comparison between the $\mathrm{HD}$ and CD voting pattern and the voting pattern for the question of feeling "too cold" for each surveyed building is established to illustrate the relationship between CD values and occupants feeling "too cold". Finally, to identify comfort, TSV and TPV are plotted against the indoor operative temperature in both a scatter and density plot. The location of the greatest density of votes for the TSV and TPV corresponding to a 0 on the seven-point scale will identify the temperature range which is most comfortable for the surveyed occupants in the building of Qatar. The comfort temperature will be extracted from this analysis and utilized as the comfortable temperature condition for further analysis. The observed temperature is extracted from the mean indoor air temperature summarized later in Table 3

\subsection{Data Simulation}

The well-regarded EnergyPlus as a whole building energy simulator is used, which has been applied in several energy studies in Qatar (Ayoub et al., 2014; Al Touma and Ouahrani, 2018; Andric and Al-Ghamdi, 2020). As a base energy model, the ANSI (American 
National Standards Institute)/ASHRAE/IES (Illuminating Engineering Society) Standard 90.1 medium office commercial prototype building energy model was used. The ANSI/ASHRAE/IES Standard 90.1 prototype buildings are intended for use in energy simulations in research and practice and are modelled as a typical building construction covering both commercial and residential building types in numerous climates. These energy models are calibrated in agreement with major institutes such as the US Department of Energy, the International Energy Conservation Code, the American National Standards Institute, ASHRAE, and the Pacific Northwest National Laboratory (PNNL) (DOE, 2021) and are summarized in Table 2. The energy model results are, in turn, validated to energy use intensities by building type based upon standard 90.1-2019 whole building energy metrics (ASHRAE, 2019). Weather data EnergyPlus Weather Format (EPW) for Doha are available from the ASHRAE International Weather for Energy Calculations (IWEC) repository.

Table 2. Summary Description of the ANSI/ASHRAE/IES Standard 90.1 Prototype Building Model. Assumed fixed clothing and metabolic rate are also shown.

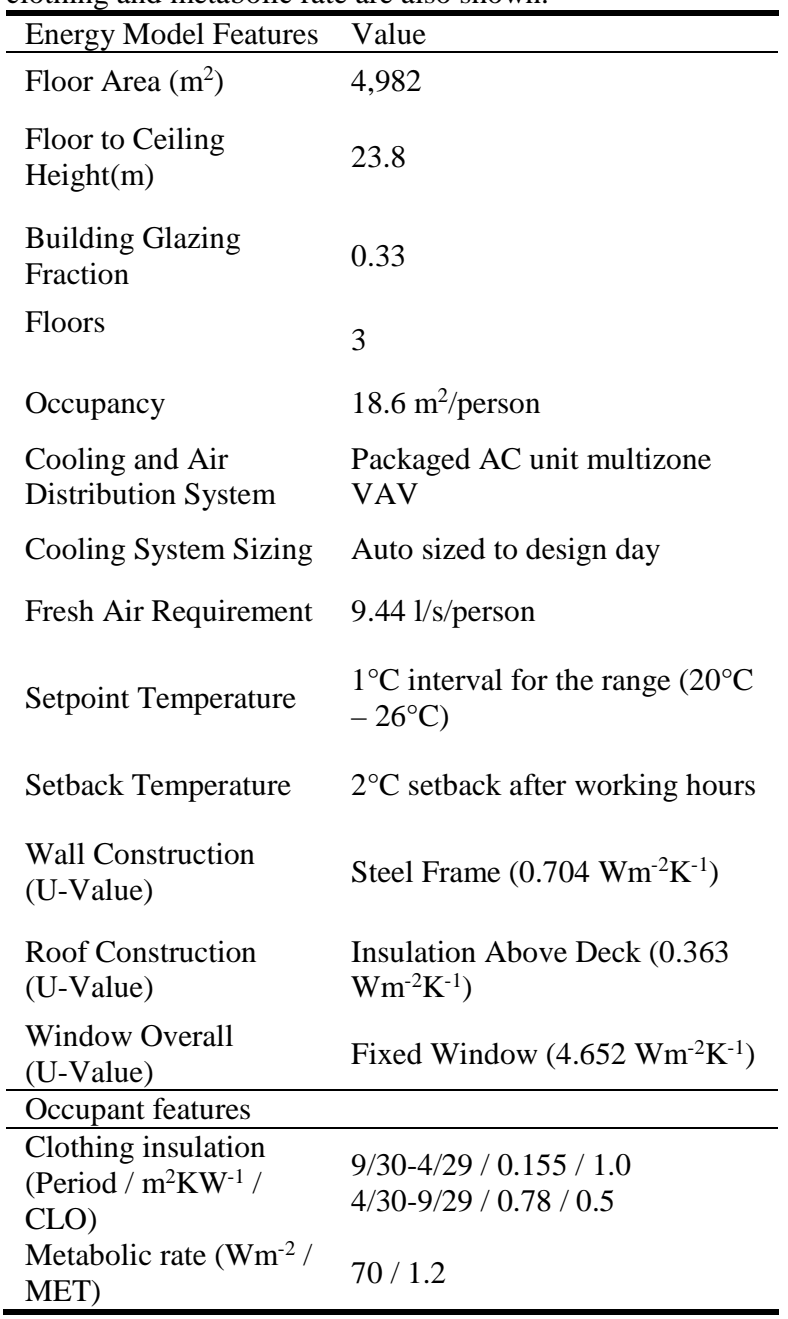

An energy simulation assessment evaluating the operation of a typical office building across the recorded indoor temperature setpoint in Qatar is conducted. The cooling temperature setpoint simulations utilize the recorded indoor temperature setpoint at $1^{\circ} \mathrm{C}$ interval for the range $\left(20^{\circ} \mathrm{C}-26^{\circ} \mathrm{C}\right)$ with a two-degree $\left({ }^{\circ} \mathrm{C}\right)$ setback after working hours for all the simulations. The seven simulations simulate the building's operation across the range of recorded indoor setpoint temperatures in a typical annual climate expected for Doha to establish the average energy demand for cooling annually. This illustrates the reduction in cooling energy demand that would be possible in the range of selected indoor temperature setpoint conditions within a typical office in Qatar.

\section{RESULTS}

Data were collected from 6 office buildings with occupants adopting similar clothing levels and a metabolic level for office seating was considered. The selected buildings were multi-storey office buildings with open planned offices and multiple occupants in the office areas, who accepted the request for field visits and data collection. A total of 330 persons participated in the questionnaires. Environmental parameters, namely air temperature $\left(\mathrm{T}_{\mathrm{a}}\right)$, mean radiant temperature $\left(T_{\mathrm{mrt}}\right)$, relative humidity $(\mathrm{RH})$, and air velocity $\left(A_{v}\right)$, were collected for the 330 participants and summarized in Table 3.

\subsection{Collection Results}

The average operative temperature $\left(\mathrm{T}_{0}\right)$ observed during the entire study is $23.5^{\circ} \mathrm{C}$, with $24.2^{\circ} \mathrm{C}$ being the average for private office buildings and $22.1{ }^{\circ} \mathrm{C}$ an average for the public office buildings. A variation in relative humidity between the private and public buildings was observed by about $10 \% \mathrm{RH}$. The overall relative humidity (RH) across all buildings was observed at $48.1 \%$ with an average of $44.6 \%$ for private buildings and $55.3 \%$ for public buildings. The air velocity $\left(A_{v}\right)$ on average didn't vary significantly between the private and public buildings as the average variation was about $0.01 \mathrm{~m} / \mathrm{s}^{2}$ and the average across all buildings was $0.16 \mathrm{~m} / \mathrm{s}^{2}$.

The average clothing insulation value (CLO) is 1.06 across all buildings. Notably, the clothing insulation value is much higher at an average of 1.21 CLO for public buildings in contrast to the average in private buildings at $0.98 \mathrm{CLO}$.

The difference between the clothing insulation value in the public and private buildings is 0.23 CLO and could be a result of an increase in formal attire in the public and governmental settings. As occupants that have assumed a prolonged seated position were surveyed, a metabolic rate (MET) of 1.20 was considered for all the buildings surveyed. 
Table 3. Measurement Summary of Indoor Environmental Parameters.

\begin{tabular}{|c|c|c|c|c|c|c|c|c|c|}
\hline Building & $\mathrm{n}$ & & $\mathrm{T}_{\mathrm{a}}$ & $\mathrm{T}_{\mathrm{r}}$ & $\mathrm{T}_{\mathrm{o}}$ & $\mathrm{RH}$ & $A_{v}$ & CLO & MET \\
\hline \multirow{4}{*}{$\begin{array}{l}\text { Private Building A } \\
\text { (Bpr A) }\end{array}$} & \multirow{4}{*}{49} & Max & 24.7 & 25.0 & 24.9 & 47.1 & 0.44 & 1.26 & - \\
\hline & & Mean & 23.8 & 24.0 & 23.9 & 43.6 & 0.11 & 0.95 & 1.20 \\
\hline & & St. Dev. & 0.9 & 0.8 & 0.8 & 1.9 & 0.08 & 0.25 & - \\
\hline & & Min & 22.3 & 22.3 & 22.3 & 40.8 & 0.01 & 0.61 & - \\
\hline \multirow{4}{*}{$\begin{array}{l}\text { Private Building B } \\
\text { (Bpr B) }\end{array}$} & \multirow{4}{*}{34} & Max & 25.1 & 25.1 & 25.1 & 60.9 & 0.68 & 1.54 & - \\
\hline & & Mean & 24.1 & 24.0 & 24.1 & 41.7 & 0.18 & 0.93 & 1.20 \\
\hline & & St. Dev. & 0.8 & 0.8 & 0.8 & 11.0 & 0.16 & 0.30 & - \\
\hline & & Min & 22.8 & 22.6 & 22.7 & 31.2 & 0.02 & 0.61 & - \\
\hline \multirow{4}{*}{$\begin{array}{l}\text { Private Building C } \\
\quad \text { (Bpr C) }\end{array}$} & \multirow{4}{*}{75} & Max & 25.8 & 25.7 & 25.7 & 41.8 & 1.28 & 1.36 & - \\
\hline & & Mean & 24.8 & 24.8 & 24.8 & 38.7 & 0.17 & 1.09 & 1.20 \\
\hline & & St. Dev. & 0.7 & 0.6 & 0.7 & 1.8 & 0.20 & 0.14 & - \\
\hline & & Min & 23.6 & 24.0 & 23.8 & 36.1 & 0.03 & 0.61 & - \\
\hline \multirow{4}{*}{$\begin{array}{l}\text { Private Building D } \\
\text { (Bpr D) }\end{array}$} & \multirow{4}{*}{68} & Max & 26.2 & 25.2 & 25.7 & 64.4 & 1.63 & 1.26 & - \\
\hline & & Mean & 24.2 & 24.3 & 24.2 & 54.4 & 0.20 & 0.97 & 1.20 \\
\hline & & St. Dev. & 0.8 & 0.6 & 0.7 & 4.7 & 0.27 & 0.24 & - \\
\hline & & Min & 22.8 & 23.3 & 23.1 & 48.4 & 0.02 & 0.61 & - \\
\hline \multirow{4}{*}{$\begin{array}{l}\text { Public Building A } \\
\text { (Bpu A) }\end{array}$} & \multirow{4}{*}{57} & Max & 24.7 & 25.6 & 25.2 & 65.3 & 0.90 & 1.54 & - \\
\hline & & Mean & 22.8 & 22.7 & 22.7 & 52.5 & 0.15 & 1.16 & 1.20 \\
\hline & & St. Dev. & 1.3 & 1.4 & 1.3 & 5.7 & 0.16 & 0.26 & - \\
\hline & & Min & 19.8 & 19.6 & 19.7 & 42.0 & 0.03 & 0.61 & - \\
\hline \multirow{4}{*}{$\begin{array}{l}\text { Public Building B } \\
\text { (Bpu B) }\end{array}$} & \multirow{4}{*}{47} & Max & 22.7 & 22.0 & 22.4 & 63.5 & 1.10 & 1.54 & - \\
\hline & & Mean & 21.7 & 21.5 & 21.6 & 58.2 & 0.20 & 1.27 & 1.20 \\
\hline & & St. Dev. & 0.3 & 0.2 & 0.3 & 4.8 & 0.19 & 0.30 & - \\
\hline & & Min & 21.2 & 21.1 & 21.2 & 49.5 & 0.02 & 0.61 & - \\
\hline
\end{tabular}

DO YOU FEEL THERMALLY COMFORTABLE?

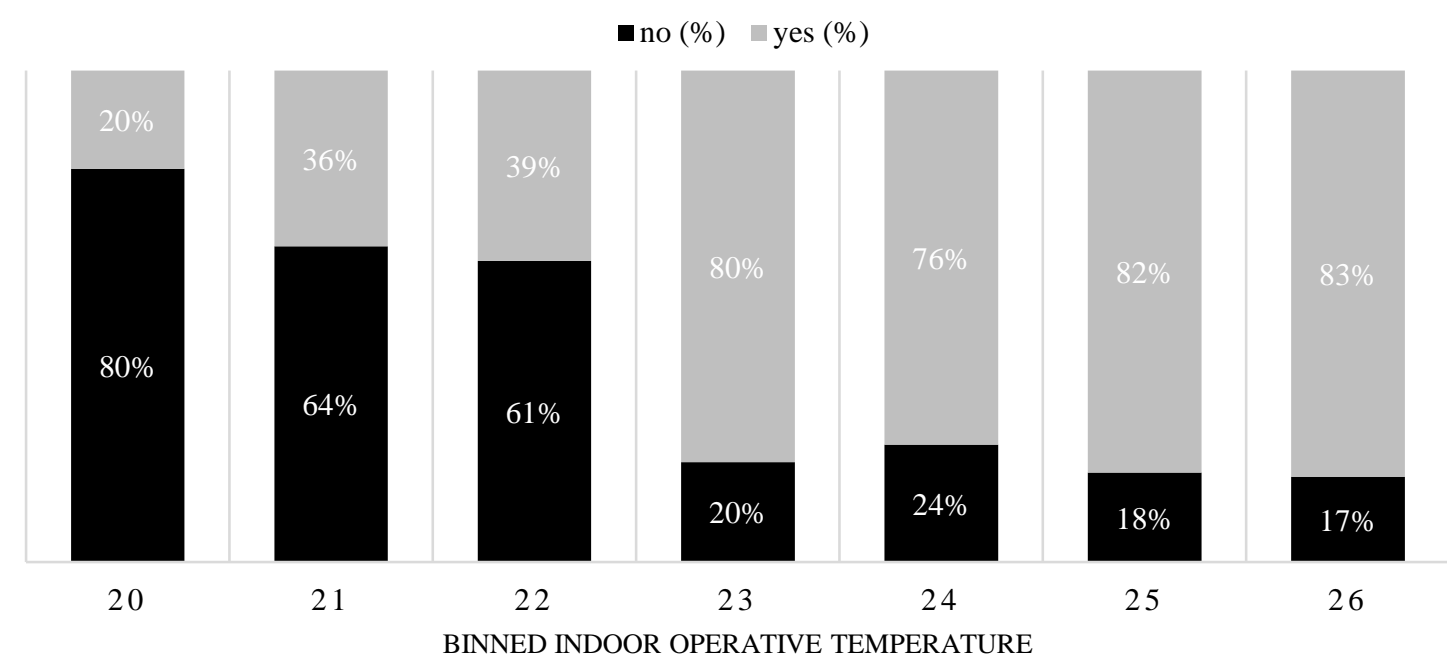

Figure 2. Occupant responses of "no" and "yes" calculated as a percentage from the entire study binned by $1{ }^{\circ} \mathrm{C}$ indoor operative temperature extracted from the questionnaire question stating, do you feel "thermally comfortable" about the thermal condition here and now?

Exploring the question measuring comfort across all the surveyed buildings, the average percentage of occupants answering "yes" which indicates that the occupant is comfortable was $70 \%$ (Figure 2). Further assessment of the question in the range of binned indoor operative temperatures, the answer of "yes" is on average below $80 \%$ in the range of $20^{\circ} \mathrm{C}$ to $22^{\circ} \mathrm{C}$ and above $80 \%$ in the range $23^{\circ} \mathrm{C}$ to $26^{\circ} \mathrm{C}$ (Figure 2). Observing the questions within the survey that ask whether the occupants are "thermally comfortable" and if they feel "too cold" under the current indoor thermal conditions highlights the occupant attitude towards comfort and cold discomfort within a typical office building in Qatar.

Likewise, exploring whether an occupant is "too cold" across all buildings through the survey question, the average percentage of occupants answering "yes" indicates that the occupant is experiencing cold the discomfort was roughly $32 \%$ (Figure 3 ). In the range of binned indoor operative temperatures, occupants are "too cold" on average above $75 \%$ in the range of $20^{\circ} \mathrm{C}$ to $22^{\circ} \mathrm{C}$ and below $25 \%$ in the range $23^{\circ} \mathrm{C}$ to $26^{\circ} \mathrm{C}$ suggesting potential comfortable indoor temperatures within the $23^{\circ} \mathrm{C}$ to $26^{\circ} \mathrm{C}$ range (Figure 3). 
DO YOU FEEL TOO COLD?

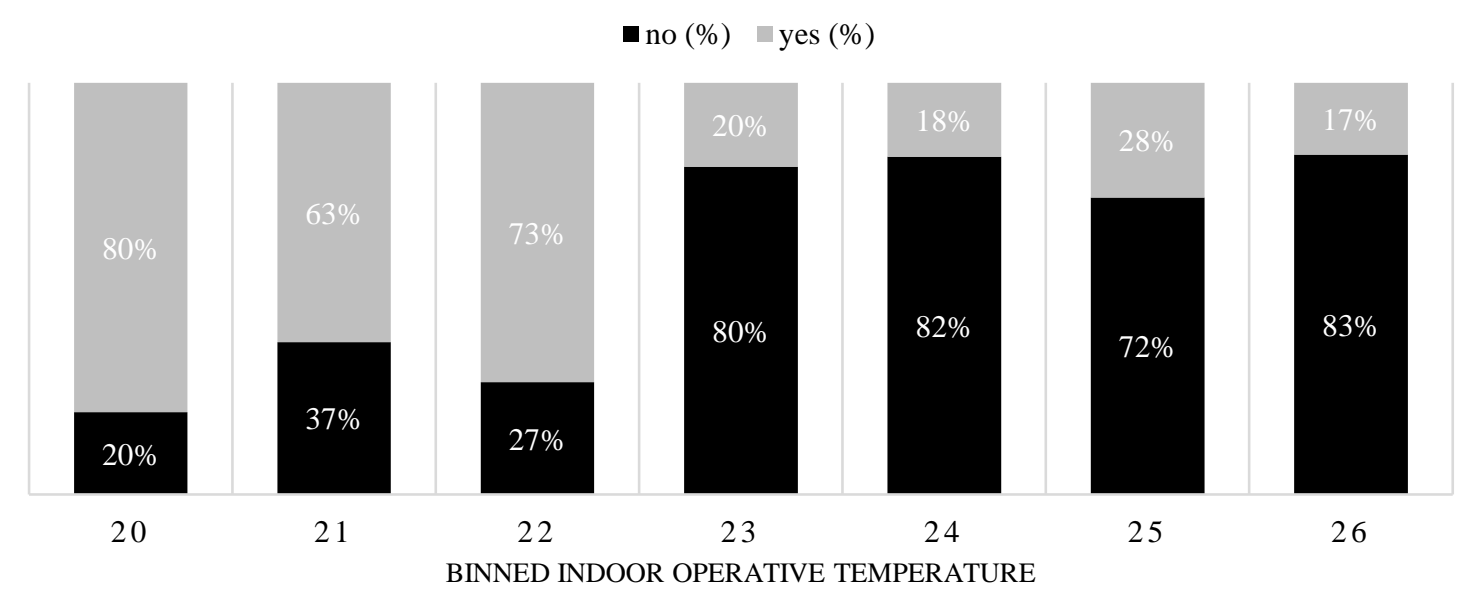

Figure 3. Occupant responses of "no" and "yes" calculated as a percentage from the entire study binned by $1{ }^{\circ} \mathrm{C}$ indoor operative temperature extracted from the questionnaire question stating, do you feel that the air conditioning here and now is creating a condition that can be called "too cold"?

Table 4. Thermal Sensation and Preference Vote Summary.

\begin{tabular}{|c|c|c|c|c|c|c|}
\hline Building & $\mathrm{n}$ & & TSV & TPV & PMV & PPD \\
\hline \multirow{4}{*}{$\begin{array}{l}\text { Private Building A } \\
\text { (Bpr A) }\end{array}$} & \multirow{4}{*}{49} & Max & 2.00 & 2.00 & 0.79 & 18.32 \\
\hline & & Mean & -0.62 & 0.08 & 0.33 & 9.95 \\
\hline & & St. Dev. & 1.09 & 0.89 & 0.36 & 4.58 \\
\hline & & Min & -3.00 & -2.00 & -0.31 & 5.00 \\
\hline \multirow{4}{*}{$\begin{array}{l}\text { Private Building B } \\
\text { (Bpr B) }\end{array}$} & \multirow{4}{*}{34} & Max & 2.00 & 2.00 & 0.88 & 21.38 \\
\hline & & Mean & -0.26 & 0.41 & 0.26 & 9.71 \\
\hline & & St. Dev. & 0.99 & 1.01 & 0.40 & 4.65 \\
\hline & & Min & -2.00 & -2.00 & -0.39 & 5.02 \\
\hline \multirow{4}{*}{$\begin{array}{l}\text { Private Building C } \\
\text { (Bpr C) }\end{array}$} & \multirow{4}{*}{75} & Max & 3.00 & 2.00 & 0.94 & 23.93 \\
\hline & & Mean & -0.02 & 0.17 & 0.66 & 15.16 \\
\hline & & St. Dev. & 1.51 & 1.06 & 0.21 & 4.82 \\
\hline & & Min & -3.00 & -2.00 & -0.02 & 5.00 \\
\hline \multirow{4}{*}{$\begin{array}{l}\text { Private Building D } \\
\text { (Bpr D) }\end{array}$} & \multirow{4}{*}{68} & Max & 3.00 & 2.00 & 0.98 & 25.61 \\
\hline & & Mean & -0.49 & 0.11 & 0.46 & 11.66 \\
\hline & & St. Dev. & 1.15 & 0.93 & 0.32 & 5.85 \\
\hline & & Min & -3.00 & -2.00 & -0.13 & 5.00 \\
\hline \multirow{4}{*}{$\begin{array}{l}\text { Public Building A } \\
\text { (Bpu A) }\end{array}$} & \multirow{4}{*}{57} & Max & 3.00 & 2.40 & 0.93 & 29.67 \\
\hline & & Mean & -0.34 & 0.06 & 0.35 & 11.34 \\
\hline & & St. Dev. & 1.57 & 1.39 & 0.42 & 5.53 \\
\hline & & Min & -3.00 & -3.00 & -1.08 & 5.11 \\
\hline \multirow{4}{*}{$\begin{array}{l}\text { Public Building B } \\
\text { (Bpu B) }\end{array}$} & \multirow{4}{*}{47} & Max & 3.00 & 2.00 & 0.70 & 15.37 \\
\hline & & Mean & -1.10 & -0.09 & 0.22 & 9.41 \\
\hline & & St. Dev. & 1.40 & 1.21 & 0.40 & 2.80 \\
\hline & & Min & -3.00 & -3.00 & -0.65 & 5.00 \\
\hline
\end{tabular}

\subsection{Analysis Results}

Analyzing the average TSV across all the buildings that have been surveyed within the study, the average value for TSV is -0.48 in contrast to a higher PMV of +0.38 averaged across all buildings. This illustrates a PMV assumption of +0.86 warmer than TSV on a sevenpoint scale $(-3$ to +3$)$ (Table 4$)$. The higher value of the PMV in contrast to TSV indicates that occupants feel much colder than expected by international standards and that any setpoint derived through such a model will result in an unintentional cold condition which would lead the occupants to feel discomfort. Additionally, averaged across private buildings TSV is -0.35 and
PMV is +0.46 which is a difference of +0.81 warmer in PMV compared to TSV. In Public buildings, TSV is -0.72 and PMV is +0.28 with a difference of +1.00 between PMV and TSV (Table 4). PPD through all buildings is on average above $10 \%$ with an average of $11.2 \%$ which indicates slightly elevated occupant discomfort. Examining TPV across all buildings surveyed, the average value of preference is closer to neutral at +0.12 on a seven-point scale $(-3$ to +3$)$ (Table 4). Examining TPV for private buildings surveyed there is a tendency to want to be slightly cooler which is observed by the value of +0.19 , however, in public buildings surveyed the preference slightly shifts to the 
negative side indicating less desire to be cooler in the public buildings (Table 4).

In contrast, hot discomfort percentages are less than $4 \%$ on average from a range of $20^{\circ} \mathrm{C}$ to $23^{\circ} \mathrm{C}$ and slightly exceed $10 \%$ starting at $24^{\circ} \mathrm{C}$ to $26^{\circ} \mathrm{C}$ with an average of $8 \%$ in that operative temperature range (Figure 4). This indicates that there are high cold discomfort percentages in cooler temperature ranges such as from $20^{\circ} \mathrm{C}$ to $23^{\circ} \mathrm{C}$ which coincides with the elevated discomfort within the public buildings as observed by the "comfort" and "too cold" questions in the survey as well as the TSV and TPV averages. Examining hot and cold discomfort percentages for the operative temperature ranges highlights that there is elevated cold discomfort in colder indoor temperatures where the cold discomfort percentage average is $47 \%$ between $20^{\circ} \mathrm{C}$ to $22^{\circ} \mathrm{C}$ and is well above $20 \%$ within that temperature range (Figure 4). In the warmer temperature ranges starting from $23^{\circ} \mathrm{C}$ to $26^{\circ} \mathrm{C}$, cold discomfort percentages were on average $13 \%$ and never exceeding 20\% within the selected binned operative temperature ranges (Figure 4).

Analysing the hot and cold discomfort percentages alongside the answers to the "too cold" question in the survey illustrates commonalities between occupants stating that they feel "too cold" and the cold discomfort percentage evaluated from the occupants TSV and TPV. The highest cold discomfort percentage observed exists in Public Building B at 30\%, likewise, the highest percentage answering yes to the "too cold" question is in Public Building B at 68\% (Figure 5). Similarly, the lowest occurrence of cold discomfort and a yes answer to the "too cold" question exists in Private Building C at $12 \%$ for CD and $15 \%$ as yes for feeling "too cold" (Figure 5). The average for cold discomfort throughout the private buildings is lower at
$13.5 \%$ to that of public buildings being at $25.5 \%$ (Figure 5). In relation to the "too cold" question, the average across private buildings is $23.3 \%$ while the average is much higher in public buildings being at $50 \%$ (Figure 5). It is noteworthy that the cold discomfort percentage arrives at lesser estimates than what is observed by the yes answers to the "too cold" question as CD takes into account both sensation and preference to determine whether an occupant is experiencing cold discomfort or not.

Assessing the occupant-voting pattern for both the TSV and TPV across the range of indoor operative temperatures collected during the study indicates the temperatures corresponding to the occupants' comfort. Significant clustering of both the TSV and TPV corresponding with the zero value on the seven-point scale suggesting occupant comfort is highest between $24^{\circ} \mathrm{C}$ to $25^{\circ} \mathrm{C}$ is observed in Figure 6. Occupant discomfort was relatively low across the private buildings based on the cold discomfort percentage (CD) only at $14 \%$ and $23 \%$ as a yes for the question about feeling "too cold". In contrast, occupant discomfort was much higher across the public buildings as (CD) was observed at $25 \%$ and $50 \%$ as a yes for feeling "too cold". The average operative temperature recorded for the private buildings was $24.2^{\circ} \mathrm{C}$, opposed to that, public buildings were on average $2^{\circ} \mathrm{C}$ colder than the private buildings with an average recorded operative temperature of $22.2^{\circ} \mathrm{C}$.

\subsection{Simulation Results}

As occupant discomfort was analyzed across a range of indoor temperatures, likewise the cooling energy demand simulations are conducted across these temperatures to represent the relationship of the cost of cooling against its impact on occupant cold discomfort.

\section{HOT AND COLD DISCOMFORT PERGENTAGES FOR BINNED INDOOR} OPERATIVE TEMPRATURE

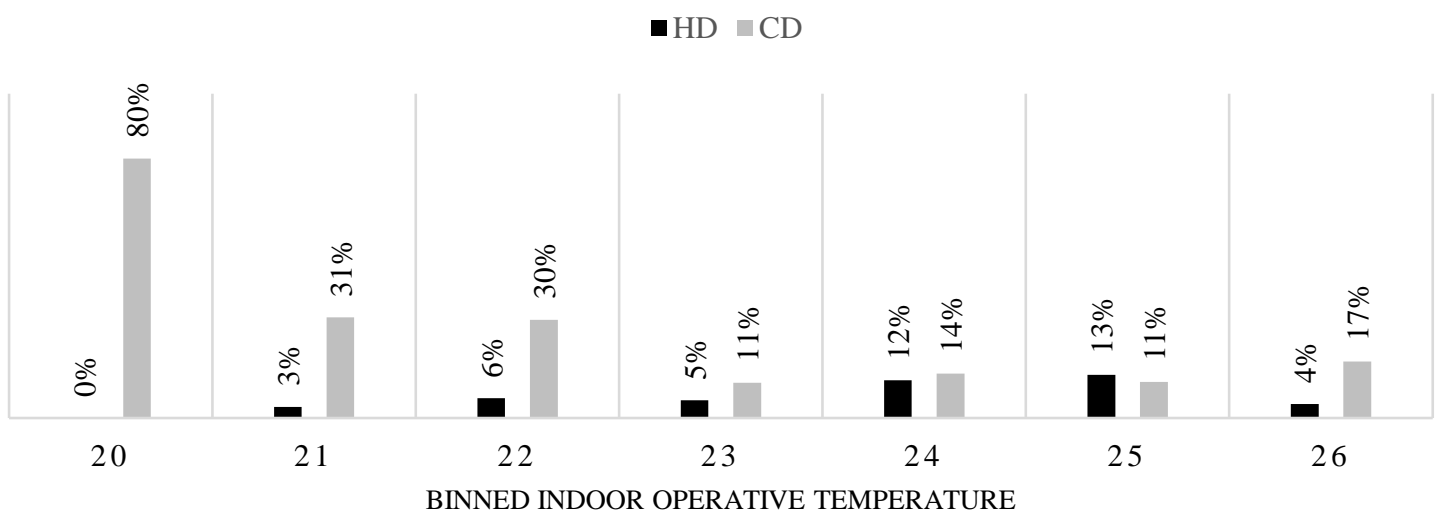

Figure 4. Hot and cold discomfort calculated as a percentage from the entire study binned by $1^{\circ} \mathrm{C}$ indoor operative temperature extracted from the combination of the thermal sensation vote and thermal preference vote. 


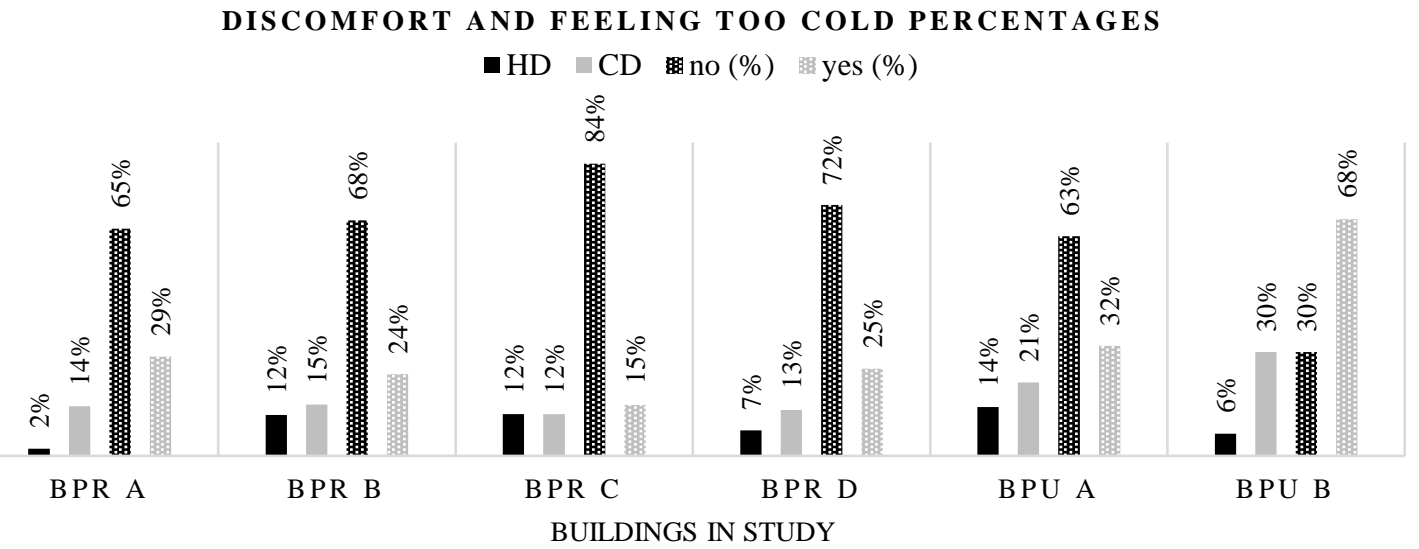

Figure 5. Hot and cold discomfort calculated as a percentage from the entire study for each building extracted from the combination of the thermal sensation vote and thermal preference vote and occupant responses of "no" and "yes" calculated as a percentage from each building in the study extracted from the questionnaire question stating, do you feel that the air conditioning here and now is creating a condition that can be called "too cold

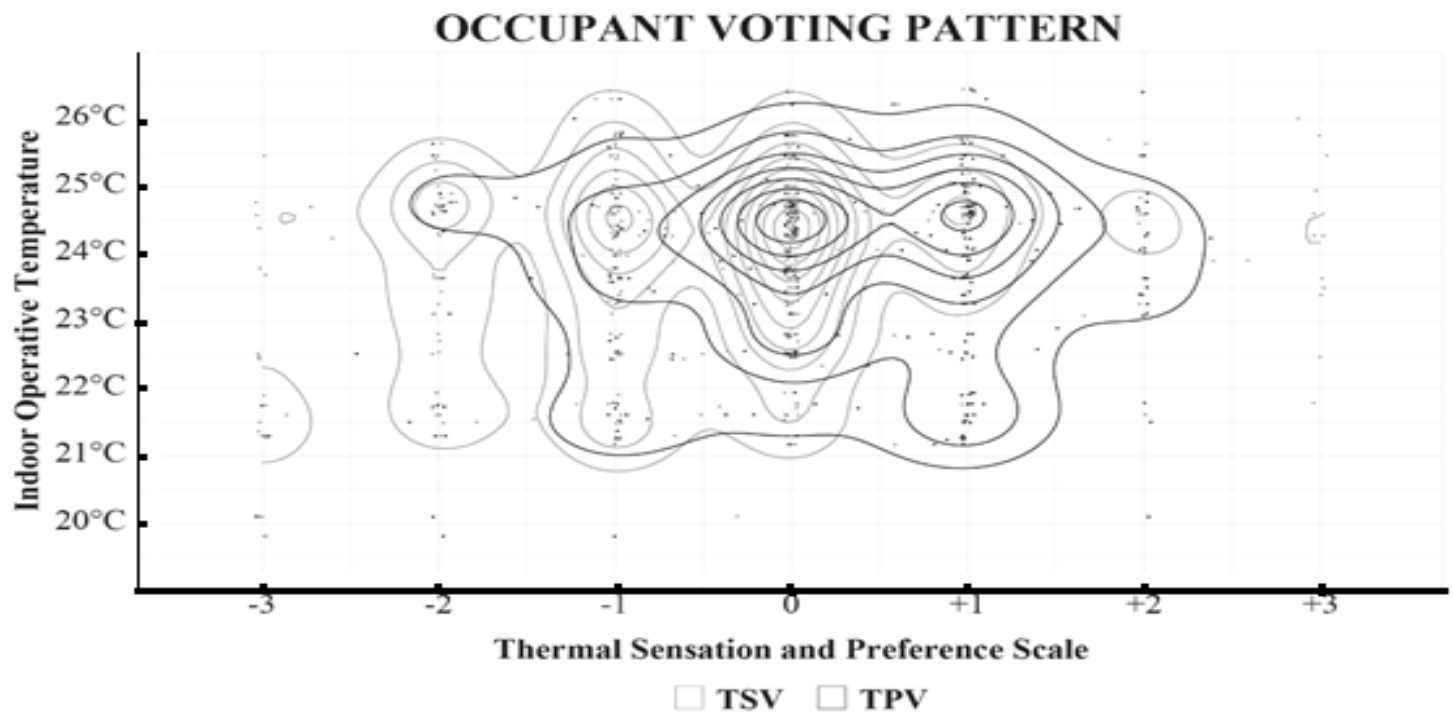

Figure 6. Occupant voting pattern for TSV and TPV on a seven-point scale across the range of operative temperatures collected across all buildings within this study.

\section{COOLING ENERGY DEMAND AND OCCUPANT DISCOMFORT FOR A RANGE OF INDOOR TEMPRATURES}

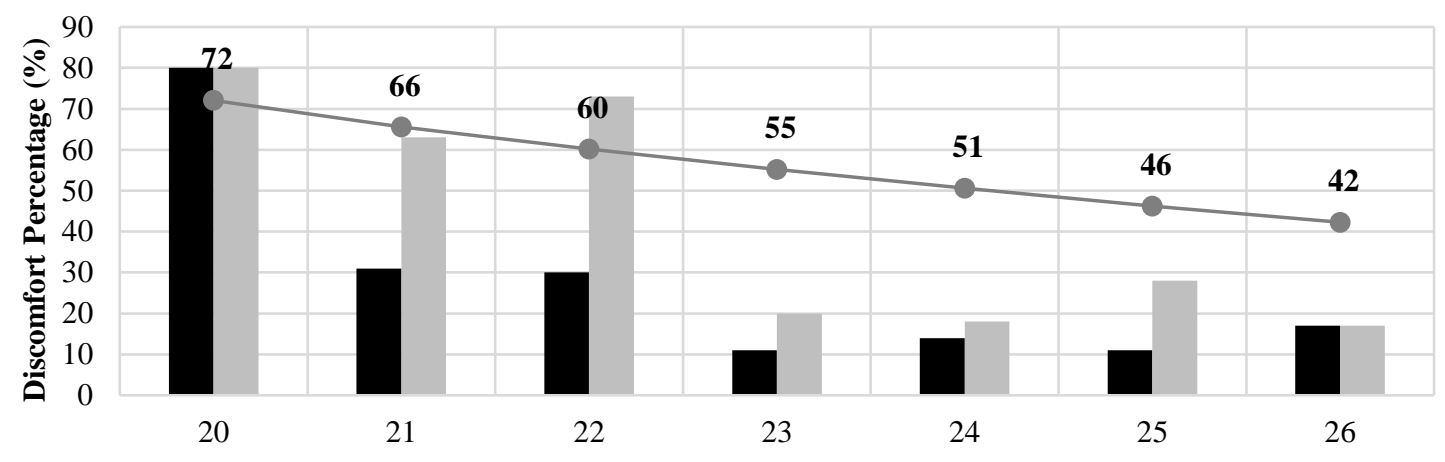

Binned Indoor Operative Temperature

CD (\%) yes (\%) —-Annual Cooling Electricity Demand

Figure 7. Annual cooling energy demand $\left(\mathrm{kWh} / \mathrm{m}^{2}\right)$ evaluated by the simulation of a typical office building alongside cold discomfort percentages and "yes" percentages from the "too cold" question across the range of indoor temperature setpoints recorded in the study. 
Throughout the energy simulations conducted, the energy demand for the entire building considering all end-uses is calculated at, a maximum energy demand of $150.8 \mathrm{kWh} / \mathrm{m}^{2}$ for the $20^{\circ} \mathrm{C}$ simulation, a minimum energy demand at $108.8 \mathrm{kWh} / \mathrm{m}^{2}$ for the $26^{\circ} \mathrm{C}$ simulation, and an average of $126.6 \mathrm{kWh} / \mathrm{m}^{2}$ across all seven simulations is recorded. The proportion of cooling energy demand as an end-use as part of the entire energy demand for the building is on average $45 \%$ across the seven simulations. A reduction in cooling energy demand is observed by an average of $8.5 \%$ for every $1{ }^{\circ} \mathrm{C}$ increase in the indoor setpoint temperature (Figure 7).

Considering the average temperature in the public buildings of $22^{\circ} \mathrm{C}$ and the average temperature in the private buildings of $24^{\circ} \mathrm{C}$, a reduction of $16 \%$ in cooling energy demand is observed (Figure 7). Further, considering the possible comfort temperature based upon occupant voting pattern of TSV and TPV in Figure 6 of $24^{\circ} \mathrm{C}$ and $25^{\circ} \mathrm{C}$, a reduction is observed of $16 \%$ and $23 \%$ respectively (Figure 7 ).

\section{DISCUSSION}

With the inexistence of local thermal comfort standards in Qatar, international thermal comfort standards, ASHRAE Standard-55 being the most prevalent, are uniformly adopted across the country. Public buildings in Qatar are more susceptible to adopting international standards as public and government-funded buildings usually adhere to regulated building practices, which would include thermal comfort policies. Additionally, as public buildings have their expenses subsidized there is less of an awareness of possible reduction of cooling energy demand as building operational costs are handled by an external entity. In contrast, in private buildings, a frugal interpretation of thermal comfort is observed, as there is a direct incentive to reduce cooling energy demand costs as the expenses are adopted directly by building owners.

Within the distributed survey across all buildings, a direct question gauging whether occupants feel "too cold" was valuable as it facilitated understanding cold discomfort in these buildings alongside the development of additional metrics such as the TSV and TPV combination to gauge cold discomfort. The cold discomfort percentage (CD) has been found to significantly mirror the number of people claiming that they are uncomfortably cold in actual occupant responses from the "too cold" question in the surveyed buildings. This provided evidence that the cold discomfort percentage can serve as an adequate metric for gauging cold thermal discomfort in buildings in future studies. The PMV in this study has been observed to assume an amplified occupant discomfort due to being too hot in comparison to what is recorded for the TSV. The use of the PMV in international thermal comfort standards in warm climates is the rationale for many discussions of excessive cooling in these climates, and a local alternative would improve the service of these climates.

Across all buildings, when cold discomfort and hot discomfort percentages were evaluated, a significant reduction in cold discomfort was observed when temperatures increased; however, this was not accompanied by an increase in hot discomfort. This would suggest that a simple intervention would be increasing the indoor setpoint temperatures to reduce both cooling energy demand and cold discomfort without an associated increase in hot discomfort for the building occupants. An overall reduction of about 8.5\% in cooling energy demand every increase in $1^{\circ} \mathrm{C}$ is significant and can contribute to the overall reduction in energy demand in warm climates as populations continue to grow and the deployment of air conditioning expands.

\subsection{Limitations and Future Research}

This study was limited to the data collected during the summer period of a single year and a longer data collection period would yield a larger collection of data. A greater number of occupant responses in a variety of indoor temperature conditions would yield a further understanding of comfort conditions in different setpoint temperature conditions. Additionally, as this study was limited to office buildings in Qatar, a more expansive view of several building typologies in Qatar could illustrate a clearer understanding of the nature of cooling in Qatar as domestic cooling is a significant consumer of energy for cooling in warm climates.

The future of active cooling due to global warming and focused urbanized population growth in warm climates will deliver massive demands for cooling across the globe. Relying on universal standards for comfort that treat the global population as equals would greatly reduce the efficiency and effectiveness of cooling and heating systems in the built environment. Domestic cooling is a possibility for future research where almost all Qatar residential units have several air conditioning devices which operate throughout the day for most of the year. Likewise, the expansion of available occupant thermal comfort data in Qatar will serve the creation of a localized thermal comfort standard for Qatar. An established standard for thermal comfort in Qatar would serve to reduce temperature setpoint which will reduce discomfort and energy consumption. A simple resolution to how warm climates considers thermal comfort in the built environment such as in this study would aid in reducing the impact of the buildings on the world which continues to face many sustainability challenges.

\section{CONCLUSION}

As global temperatures continue to rise, and the human population continues to grow in warmer climates, the dependency on air condition and its utilization in the built environment is expected to expand considerably. 
Overcooling in buildings is an unnecessary use of energy causing building occupants to feel cold discomfort, which is a significant drawback to the thermal comfort and energy efficiency of buildings in warm climates.

The existence of overcooling in office buildings in Qatar and can be minimized through simple interventions such as an increase in the indoor setpoint temperature. Looking through the range of indoor temperatures and discomfort levels in the data, cold discomfort can be reduced significantly without an increase in hot discomfort, which, on average, occurs at a setpoint temperature that is about $2^{\circ} \mathrm{C}$ warmer from ASHRAE-55 suggestions. Applying energy simulations, it is found that an increase in indoor setpoint would reduce cooling energy demand by around $8.5 \%$ for every $1{ }^{\circ} \mathrm{C}$.

Through the appropriate application of localized thermal comfort standards developed based on local data and analysis, applicable indoor setpoint temperatures can be developed for Qatar. Utilizing the appropriate indoor temperature setpoints, an increase in occupant comfort and a reduction of energy consumption can be achieved.

\section{CONFLICT OF INTEREST}

The authors declare no conflict of interest.

\section{FUNDING}

Abdulla Alnuaimi's doctoral research is supported by the Qatar University Scholarships Program.

\section{REFERENCES}

Abou-Ziyan, H., Alajmi, A. and Ghoneim, A. (2016) 'Sustainable Solution for Energy Needs of Existing Building in Kuwait', Researchgate.Net, (May 2017). Available at: https://www.researchgate.net/profile/Ali_Alajmi2/ publication/316738614_Sustainable_Solution_for _Energy_Needs_of_Existing_Building_in_Kuwait /links/59101da14585159781875e85/SustainableSolution-for-Energy-Needs-of-Existing-Buildingin-Kuwait.pdf.

Aghniaey, S. and Lawrence, T. M. (2018) 'The impact of increased cooling setpoint temperature during demand response events on occupant thermal comfort in commercial buildings: A review, Energy and Buildings. Elsevier, 173, pp. 19-27.

Alnuaimi, A. N. and Natarajan, S. (2020) 'The Energy Cost of Cold Thermal Discomfort in the Global South', Buildings. Multidisciplinary Digital Publishing Institute, 10(5), p. 93.

Andric, I. and Al-Ghamdi, S. G. (2020) 'Climate change implications for environmental performance of residential building energy use: The case of Qatar', Energy Reports. Elsevier, 6, pp.
$587-592$.

ASHRAE (2010) 'Standard 55-2010, Thermal environmental conditions for human occupancy', American Society of Heating, Refrigerating and Air Conditioning Engineers.

ASHRAE (2019) 'ANSI/ASHRAE/IES Standard 90.12019', Energy Standard for Buildings Except LowRise Residential Buildings.

Auliciems, A. and De Dear, R. (1986) 'Air conditioning in a tropical climate: Impacts upon European residents in Darwin, Australia', International Journal of Biometeorology, 30(3), pp. 259-282. doi: 10.1007/BF02189471.

Ayoub, N. et al. (2014) 'Energy consumption and conservation practices in Qatar - A case study of a hotel building', Energy and Buildings. Elsevier Ltd, 84, pp. 55-69. doi: 10.1016/j.enbuild.2014.07.050.

Bennett, D. H. et al. (2012) 'Ventilation, temperature, and HVAC characteristics in small and medium commercial buildings in California', Indoor Air, 22(4), pp. 309-320. doi: 10.1111/j.16000668.2012.00767.x.

Brager, G. and Arens, E. (2015) 'Creating high performance buildings: Lower energy, better comfort', in AIP Conference Proceedings. American Institute of Physics, pp. 58-69.

CEN (2007) 'EN 15251: indoor environmental input parameters for design and assessment of energy performance of buildings addressing indoor air quality, thermal environment, lighting and acoustics', Thermal Environment, Lighting and Acoustics, CEN, Brussels.

Cena, K. and De Dear, R. (2001) 'Thermal comfort and behavioural strategies in office buildings located in a hot-arid climate', Journal of Thermal Biology. Elsevier, 26(4-5), pp. 409-414.

Chen, A. and Chang, V. W.-C. (2012) 'Human health and thermal comfort of office workers in Singapore', Building and Environment. Elsevier, 58, pp. 172-178.

CIBSE (2015) Environmental Design CIBSE guide A. 8th ed. CIBSE.

De Dear, R. and Brager, G. S. (1998) 'Developing an adaptive model of thermal comfort and preference'.

Derrible, S. and Reeder, M. (2015) 'The cost of overcooling commercial buildings in the United States', Energy and Buildings. Elsevier, 108, pp. 304-306. doi: 10.1016/j.enbuild.2015.09.022.

DOE (2021) EnergyPlus. Available at: https://energyplus.net/ (Accessed: 2 December 2019).

EIA (2019) ‘Annual Energy Outlook 2019’, U.S. Energy Information Administration Annual Energy Outlook. Available at: https://www.eia.gov /outlooks/aeo/pdf/aeo2019.pdf.

Elnaklah, R. et al. (2021) 'Thermal comfort standards in the Middle East: Current and future challenges', Building and Environment. Elsevier, 200, p. 107899. 
EN, E. U. S. (2019) ‘16798-1: 2019’, Energy Performance of Buildings-Ventilation for Buildings-Part, 1.

Estrella Guillén, E., Samuelson, H. W. and Cedeño Laurent, J. G. (2019) 'Comparing energy and comfort metrics for building benchmarking', Energy and Buildings, 205. doi: 10.1016/j.enbuild.2019.109539.

Fang, X., Winkler, J. and Christensen, D. (2011) 'Using EnergyPlus to perform dehumidification analysis on building America homes', HVAC and R Research, 17(3), pp. 268-283. doi: 10.1080/10789669.2011.564260.

Fanger, P. (1970) Thermal Comfort: Analysis and Applications in Environmental Engineering. New York, : McGraw-Hill.

GORD (2019) 'GSAS 2019 DESIGN \& BUILD GUIDELINES MANUAL’.

Green, P. (2019) Do Americans Need AirConditioning?, New York Times. Available at: www.nytimes.com/2019/07/03/style/air-condition ing -obsession.html. (Accessed: 2 February 2019).

Havenith, G. et al. (2015) 'A Database of Static Clothing Thermal Insulation and Vapor Permeability Values of Non-Western Ensembles for Use in ASHRAE Standard 55, ISO 7730, and ISO 9920', ASHRAE Transactions, 121, pp. 197215.

Hu, J. and Karava, P. (2014) 'Model predictive control strategies for buildings with mixed-mode cooling', Building and Environment. Elsevier Ltd, 71, pp. 233-244. doi: 10.1016/j.buildenv.2013.09.005.

Huh, J. H. and Brandemuehl, M. J. (2008) 'Optimization of air-conditioning system operating strategies for hot and humid climates', Energy and Buildings, 40(7), pp. 1202-1213. doi: 10.1016/j.enbuild.2007.10.018.

Humphreys, M. A. and Nicol, J. F. (2002) 'The validity of ISO-PMV for predicting comfort votes in everyday thermal environments', Energy and buildings. Elsevier, 34(6), pp. 667-684.

IEA (2018) 'The Future of cooling. Opportunities for energy-efficient air conditioning.', p. 90. doi: 10.1016/S0181-5512(07)79285-9.

Indraganti, M. and Boussaa, D. (2017) 'Comfort temperature and occupant adaptive behavior in offices in Qatar during summer', Energy and Buildings. Elsevier, 150, pp. 23-36.

ISO (2005) 'BS EN ISO 7730: 2005: Ergonomics of the Thermal Environment. Analytical Determination and Interpretation of Thermal Comfort Using Calculation of the PMV and PPD Indices and Local Thermal Comfort Criteria'. International Standards Organization Geneva.

Kaam, S. et al. (2017) 'Time-averaged ventilation for optimized control of variable-air-volume systems', Energy and Buildings. Elsevier B.V., 139, pp. 465475. doi: 10.1016/j.enbuild.2016.11.059.

Köppen, W. (1918) 'Classification of climates according to temperature, precipitation and seasonal cycle', Petermanns Geogr. Mitt, 64(1918), pp. 193-203.

Landsman, J., Brager, G. and Doctor-Pingel, M. (2018) 'Performance, prediction, optimization, and user behavior of night ventilation', Energy and Buildings. Elsevier B.V., 166, pp. 60-72. doi: 10.1016/j.enbuild.2018.01.026.

May-Ostendorp, P. et al. (2011) 'Model-predictive control of mixed-mode buildings with rule extraction', Building and Environment. Elsevier Ltd, 46(2), pp. 428-437. doi: 10.1016/j.buildenv.2010.08.004.

Mendell, M. J. and Mirer, A. G. (2009) 'Indoor thermal factors and symptoms in office workers: findings from the us epa base study', Indoor Air, 19(4), pp. 291-302. doi: 10.1111/j.1600-0668.2009.00592.x.

Murphy, K. (2015) Enduring Summer's Deep Freeze, New York Times. Available at: www. nytimes.com/2015/07/05/sunday-review/enduringsummers-deep-freeze.html.\%0A (Accessed: 2 February 2019).

Paliaga, G. et al. (2019) 'Eliminating overcooling discomfort while saving energy', ASHRAE Journal, 61(4), pp. 14-28.

Palme, M. et al. (2007) 'Dynamic sensation of comfort in buildings: the temperature changes effects', ... 28 the Conference and 2 nd ..., 2(September), pp. 746-750.

Pisello, A. L. and Cotana, F. (2014) 'The thermal effect of an innovative cool roof on residential buildings in Italy: Results from two years of continuous monitoring', Energy and Buildings. Elsevier B.V., 69, pp. 154-164. doi: 10.1016/j.enbuild.2013.10.031.

Samiuddin, S. and Budaiwi, I. M. (2018) 'Assessment of thermal comfort in high-occupancy spaces with relevance to air distribution schemes: A case study of mosques', Building Services Engineering Research and Technology, 39(5), pp. 572-589. doi: 10.1177/0143624418764769.

Shi, Z. et al. (2015) 'Digital campus innovation project: Integration of Building Information Modelling with building performance simulation and building diagnostics', Simulation Series, 47(7), pp. 51-58.

Stocker, T. F. et al. (2013) 'Climate change 2013: The physical science basis’. Cambridge University Press Cambridge.

Toftum, J. and Fanger, P. (2002) 'Extension of the PMV model to non-air-conditioned buildings in warm climates', Energy and Buildings, 34(6), pp. 533-536. doi: 10.1016/S0378-7788(02)00003-8.

Al Touma, A. and Ouahrani, D. (2018) 'The selection of brise soleil shading optical properties for energy conservation and glare removal: A case study in Qatar', Journal of Building Engineering. Elsevier, 20, pp. 510-519.

Wang, W. et al. (2017) 'Energy conservation through flexible HVAC management in large spaces: An IPS-based demand-driven control (IDC) system', 
Automation in Construction. Elsevier, 83(August), pp. 91-107. doi: 10.1016/j.autcon.2017.08.021.

Williams, E. (2016) Overcooling and Overheating Buildings Emits as Much Carbon as Four Million Cars., The Conversation. Available at: www.theconversation.com/overcooling-andoverheating-buildings-emits-as-much-carbon-asfour-million-cars-64950. (Accessed: 2 February 2019).

Yang, W., Wong, N. H. and Zhou, J. (2014)
'Overcooling and thermal comfort in air conditioned university buildings in Singapore', Indoor Air 2014 - 13th International Conference on Indoor Air Quality and Climate, 554, pp. 546-553. Zhou, X. et al. (2016) 'Influence of asynchronous demand behavior on overcooling in multiple zone AC systems', Building and Environment. Elsevier Ltd, 110, pp. 65-75. doi: 10.1016/j. buildenv.2016.10.001. 